\title{
Title:
}

\section{Pancreatic lipoma: diagnostic boom of a rare mesenchymal tumor}

\section{Authors:}

Alberto Díaz García, Javier Padilla Quintana, Pablo Sanz Pereda, Jesús Ignacio Vivancos Garbayo, Pilar Elena González de Chaves Rodríguez, Betsabé Reyes Correa, Manuel Ángel Barrera Gómez

DOI: $10.17235 /$ reed.2022.8536/2021

Link: PubMed (Epub ahead of print)

Please cite this article as:

Díaz García Alberto, Padilla Quintana Javier, Sanz Pereda Pablo , Vivancos Garbayo Jesús Ignacio , González de Chaves Rodríguez Pilar Elena, Reyes Correa Betsabé , Barrera Gómez Manuel Ángel . Pancreatic lipoma: diagnostic boom of a rare mesenchymal tumor. Rev Esp Enferm Dig 2022. doi: 10.17235/reed.2022.8536/2021.

This is a PDF file of an unedited manuscript that has been accepted for publication. As a service to our customers we are providing this early version of the manuscript. The manuscript will undergo copyediting, typesetting, and review of the resulting proof before it is published in its final form. Please note that during the production process errors may be discovered which could affect the content, and all legal disclaimers that apply to the journal pertain. 


\section{Pancreatic lipoma: diagnostic boom of rare mesenchymal tumor}

- Alberto Díaz García (a), Servicio Cirugía General y Digestiva, Hospital Universitario Nuestra Señora de Candelaria, Tenerife, España

- Javier Padilla Quintana (a), Servicio Cirugía General y Digestiva, Hospital Universitario Nuestra Señora de Candelaria, Tenerife, España

- Pablo Sanz Pereda (a), Servicio Cirugía General y Digestiva, Hospital Universitario Nuestra Señora de Candelaria, Tenerife, España

- Jesús Ignacio Vivancos Garbayo (b), Servicio de Radiología, Hospital Universitario Nuestra Señora de Candelaria, Tenerife, España

- Pilar Elena González de Chaves Rodríguez (a), Servicio Cirugía General y Digestiva, Hospital Universitario Nuestra Señora de Candelaria, Tenerife, España

- Betsabé Reyes Correa (a), Servicio Cirugía General y Digestiva, Hospital Universitario Nuestra Señora de Candelaria, Tenerife, España.

- Manuel Ángel Barrera Gómez (a), Servicio Cirugía General y Digestiva, Hospital Universitario Nuestra Señora de Candelaria, Tenerife, España

Coresspondence: Alberto Díaz García

Email: alber.dg.med@gmail.com

Dear Editor,

Following the incidental finding of a tumor in a 58-year-old female, diagnosed as pancreatic lipoma, histologically confirmed by fine-needle aspiration biopsy (FNAB) with endoscopic ultrasound (EUS), we made a review in our center between 2018 and 2020, with 14 cases diagnosed of pancreatic lipoma by computarized tomography (CT) or magnetic resonance imaging (MRI).

\section{$\underline{\text { Discussion }}$}


Mesenchymal tumors, including pancreatic lipomas, are very rare and only account for 1-2\% of all pancreatic neoplasms (1). Through the case series and case studies reported, it seems that there is a slight higher prevalence among women and of lipomas located in the pancreatic head (2).

The scientific literature of this pathology describes a low incidence, although it is likely that it is higher than previously thought. There may be a greater identification of this type of tumors thanks to the increasing use of medical imaging tests, their greater availability and the better image quality (3). Both CT and MRI have high sensitivity and specificity for the diagnosis of pancreatic lipomas. If there is a diagnostic doubt, obtaining a histological sample by EUS-FNAB is indicated as the technique of choice (4). Once the diagnosis is reached, the management of these tumors is generally conservative, based on radiological follow-up. Surgical treatment is performed only for symptomatic cases or in case there are suspicious findings in imaging tests and histological samples (3). The multidisciplinary committees of pancreatic tumors have been key to joint decision-making both in the diagnosis and management of pancreatic lipomas.

\section{BIBLIOGRAFÍA}

1. Lee, S., 2011. Lipoma of the pancreas, a case report and a review of the literature. World Journal of Radiology, 3(10), p.246.

2. Butler, J., Fohtung, T., Sandrasegaran, K., et al. 2016. The natural history of pancreatic lipoma: Does it need observation. Pancreatology, 16(1), pp.95-98.

3. Stadnik A, Cieszanowski A, Bakon L, et al. Pancreatic lipoma: an incydentaloma which can resemble cancer e analysis of 13 cases studied with CT and MRI. Pol J Radiol 2012;77:9e13.

4. Herranz Pérez Raquel, de la Morena López Felipe, Jiménez-Heffernan José, et al. Intermittent endoscopic ultrasound guided fineneedle aspiration for the diagnosis of solid pancreatic lesions. A pilot study. Rev Esp Enferm Dig 2021

5. Ahmad, M., Husain, M., Wani, A. et al., 2016. Pancreatic Lipoma - A Case Report With Review Of Literature. JOP. J Pancreas, pp.17(6):675-678. 


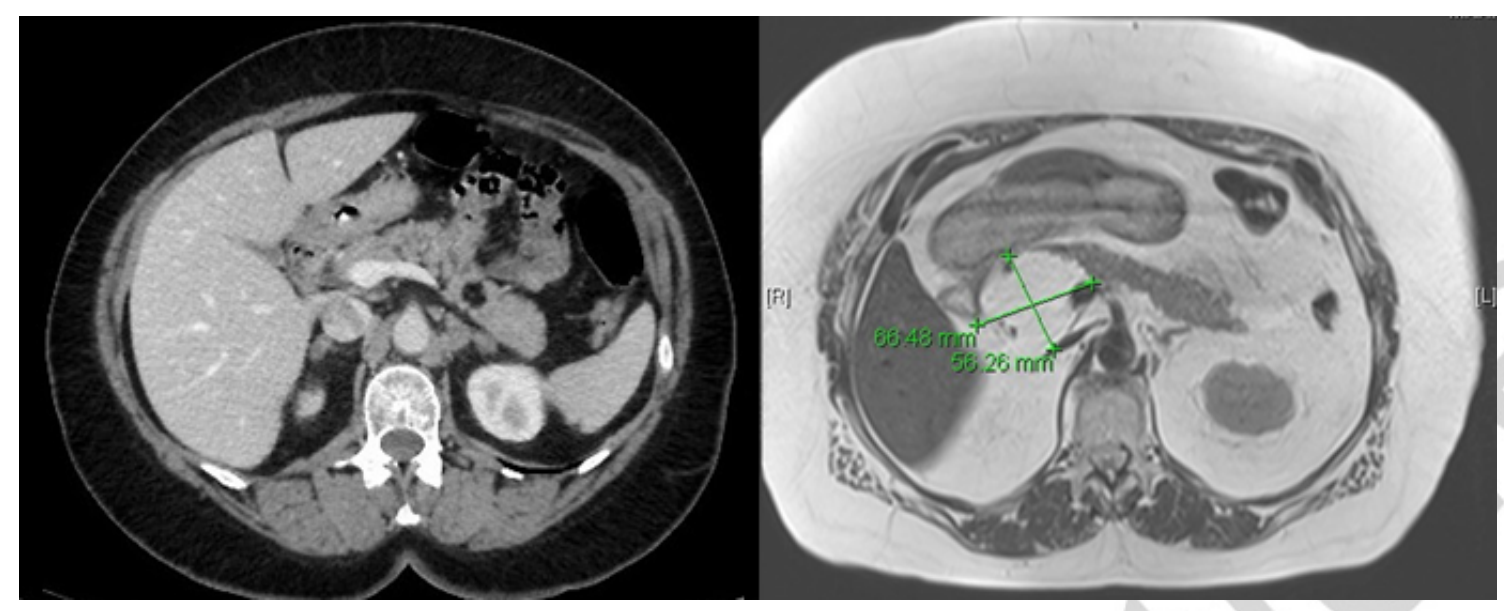

Figure 1. On the left, axial CT image of 54 year-old patient with incidental finding of $12 \times 14 \mathrm{~mm}$ lesión in the pancreatic tail with characteristics compatible with pancreatic lipoma. On the right, axial image por the MRI in 60 year-old patient with incidental finding of $66 \times 56 \mathrm{~mm}$ lesión in the pancreatic head with characteristics compatible with pancreatic lipoma. 